\title{
Pandangan Terhadap Fenomena Gentrifikasi dan Hubungannya dengan Perencanaan Spasial
}

\author{
Azka Nur Medha, Putu Gde Ariastita \\ Departemen Perencanaan Wilayah dan Kota, Fakultas Teknik Sipil dan Perencanaan, Institut \\ Teknologi Sepuluh Nopember (ITS) \\ e-mail: ariastita@urplan.its.ac.id
}

\begin{abstract}
Abstrak-Perencanaan spasial di Indonesia bersandar pada pendekatan Rational Comprehensive Planning (RCP), yang cenderung mengasumsikan bahwa seorang perencana merupakan pihak dengan kepemilikan ilmu yang kompeten sehingga mampu merencanakan apa yang sesuai untuk masyarakat. Namun, fakta menunjukan bahwa produk perencanaan di Indonesia memperlihatkan adanya gap yang cukup besar antara pengetahuan perencana dengan masyarakat sebagai klien utama seorang perencana. Maka dari itu, diperlukan dedikasi yang tinggi bagi akademisi untuk mengeksplor lebih dalam lagi mengenai fenomena-fenomena perkotaan yang sudah terlihat nyata keberadaannya. Artikel ini membahas suatu fenomena perkotaan yang diberi istilah gentrifikasi, dimana istilah ini masih relatif asing untuk dibahas dalam proses perencanaan di Indonesia. Gentrifikasi diyakini sebagai fenomena perkotaan yang memberikan dampak negatif pada masyarakat yang mengalaminya. Disisi lain, gentrifikasi memberikan sebuah pandangan yang meyakinkan bahwa suatu proses perencanaan yang dimiliki oleh domain publik harus memakai pendekatanpendekatan sosial untuk menghasilkan produk perencanaan yang lebih kontekstual.
\end{abstract}

Kata Kunci-perencanaan, gentrifikasi, pendekatan sosial (social approach), rational comprehensive planning.

\section{PENDAHULUAN}

I LMU perencanaan pada awalnya memang berfokus pada aspek desain lingkungan fisik atau disebut juga sebagai morphologycal conception of space [1]. Sampai dengan akhir abad ke-19, perkembangan perencanaan tidak dibatasi sampai dengan perencanaan fisik saja, melainkan berkembang menjadi ilmu metadisiplin dengan cakupan ilmu yang begitu luas [2]. Tentunya, hal ini didasari atas fakta-fakta yang mengungkap bahwa perencanaan tidak akan berhasil dengan memperhatikan aspek fisik saja. Pengakuan akan ilmu perencanaan yang bersifat metadisiplin muncul pada negara maju terlebih dahulu [3]. Meskipun mengalami kecanggungan pada permulaan penerimaan paham intelektual perencanaan yang harus memperhatikan aspek lain seperti ekonomi dan sosial, namun sekarang ilmu perencanaan yang bersifat metadisiplin relatif sudah diakui oleh berbagai negara, termasuk negara berkembang seperti Indonesia [2].

Seperti yang sudang disinggung sebelumnya bahwa pengakuan ilmu perencanaan yang bersifat metadisiplin didorong oleh fakta-fakta masalah perkotaan yang bersinggungan dengan masalah sosial, fenomena gentrifikasi merupakan salah satu fenomena yang berkembangan dan menjadi objek ketertarikan studi sendiri bagi para akademisi dalam bidang perkotaan. Istilah gentrifikasi mulai diperkenalkan pada periode 1960an di Inggris [4], dan kemudian berkembang di Amerika Serikat setelahnya. Fenomena gentrifikasi merupakan bahasan yang mengantarkan pada sebuah kesimpulan bahwa aspek sosial merupakan bagian dalam sebuah perencanaan.

Gentrifikasi dimaknai dengan beragam definisi oleh para ahli, karena kertekaitannya dengan perubahan kawasan yang dinamis dan menyinggung masalah sosial budaya yang menjadikannya sebuah masalah yang kompleks. Sederhananya, gentrifikasi merupakan proses transformasi tata guna lahan yang diikuti dengan perubahan kawasan permukiman masyarakat berpenghasilan rendah [5]. Selanjutnya, terjadilah sebuah proses yang menjadikan kawasan tersebut tergantikan dengan masyarakat berpenghasilan tinggi [6]. Berdasarkan definisi tersebut, dapat disimpulkan bahwa fenomena gentrifikasi muncul akibat adanya proses peningkatan suatu kawasan yang telah sukses menarik perhatian masyarakat golongan kaya, dan menciptakan kedinamisan wilayah dimana hal tersebut akan menstimulasi kenaikan harga properti yang harganya diluar jangkauan masyarakat semula, sehingga masyarakat menjadi rentan untuk terusir dari kawasan huniannya. Gentrifikasi jelas merupakan sebuah fenomena yang mengancam eksistensi suatu masyarakat karena akibatakibat dari naik kelas nya sebuah kawasan menjadi kawasan yang bernilai tinggi, dimana masyarakat menjadi tidak sanggup untuk menyesuaikan diri dengan kawasan tersebut.

Dari studi-studi tentang gentrifikasi di Indonesia yang sudah dilakukan sebelumnya, gentrifikasi seringkali dikaitkan dengan kegiatan revitalisiasi, rehabilitasi, peremajaan dan peningkatan kawasan, dan merupakan sebuah konotasi yang bermakna negatif. Hal ini semata-mata karena hasil dari proses gentrifikasi dimana terdapat pihak yang tergusur (gentrified) dan pihak yang menggusur (gentrifier). Sebuah fenomena gentrifikasi yang teridentifikasi di Indonesia dalam literatur penelitian antara lain adalah kasus pembangunan rumah susun Kebon Kacang di Jakarta pada dekade 1980an awal dan kasus peremajaan kawasan Segitiga Senen, Jakarta pada akhir periode 1980an [7]. Kedua kasus ini menggambarkan bahwa dalam prosesnya, peningkatan kawasan yang tujuan utamanya adalah untuk perbaikan fisik ternyata dalam kasus-kasus tertentu justru menimbulkan masalah baru, yaitu gentrifikasi. Kerugian tentunya didapat oleh pihak yang tergusur, dimana mereka terusir secara ekonomi karena tidak mampu 
menyesuaikan dengan kenaikan pajak lahan dan kebutuhan biaya hidup yang baru, adanya tekanan psikologi karena pergeseran struktur sosial penduduk, munculnya kebencian dan konflik dengan komunitas baru, dan hilangnya hunian yang terjangkau [8] .

Apabila dilihat berdasarkan pemaknaan istilah gentrifikasi sendiri, maka dapat disimpulkan bahwa gentrifikasi merupakan suatu fenomena perkotaan yang timbul apabila dilihat dari sudut pandang aspek sosial, dan tidak bisa diselesaikan dengan metode perencanaan yang hanya memperhatikan aspek fisik saja. Meskipun begitu, fenomena ini belum banyak dibahas di kota-kota di Indonesia meskipun dampaknya sudah sering dirasakan. Bukan terhadap dampak pembangunan itu sendiri, namun lebih kepada masyarakat yang mengalaminya. Konsekuensi terhadap perencanaan karena hal tersebut adalah sampai saat ini belum ada solusi yang dapat ditawarkan untuk menyelesaikan keadaan-keadaan baik yang masih berupa gejala, atau sudah terjadinya gentrifikasi.

Ketertinggalan Indonesa dalam menanggapi gentrifikasi dibandingkan dengan negara maju sebenarnya beralasan, mengingat peranan aspek sosial yang menjadi fokus utama dalam memahami gentrifikasi bukan menjadi hal yang familiar, bahkan cenderung masih canggung untuk dibahas. Fokus perencanaan di Indonesia masih berat pada penyediaan dan penataan prasarana fisik, sementara aspek sosial masih kurang mendapat perhatian [9]. Padahal perencanaan diperlukan dalam rangka mewujudkan berbagai pihak dalam domain publik melalui pemeliharaan fisik, ekonomi, dan kehidupan sosial. Artikel ini akan membahas mengenai fenomena gentrifikasi dan bagaimana seorang perencana harus memandang fenomena tersebut dalam suatu proses perencanaan.

\section{METODOLOGI}

Artikel ini merupakan sebuah tulisan dengan metode ulasan (review) literatur. Penyusunan artikel diawali dengan mengulas literatur secara global baik itu dari buku, jurnal, makalah proses (proceedings paper) dan tulisan lainnya yang menunjang. Publikasi yang terpilih diproses dengan menyaring kutipan-kutipan dan menarik peristiwa yang teridentifikasi pada penelitian sebelumnya, yang disesuaikan dengan tema yang diangkat pada penulisan artikel ini.

\section{MENGENAL ISTILAH GENTRIFIKASI DAN PENGGUSURAN (DISPLACEMENT), DAN PERBEDAAN ANTARA KEDUANYA}

Perdebatan dalam pendefinisian gentrifikasi terletak pada proses displacement, yaitu ketika masyarakat penghuni semula tergantikan dengan seutuhnya dengan masyarakat pendatang yang lebih mampu. Beberapa definisi menyatakan bahwa fenomena yang sudah dapat dikatakan sebagai gentrifikasi sudah mencakup proses displacement didalamnya, namun beberapa membantah dengan menyatakan bahwa displacement merupakan proses yang terpisah.

Istilah gentrifikasi pertama kali diperkenalkan sebagai sebuah potret ketidakserasian dan ketidakadilan kelas sosial yang diciptakan karena adanya kapitalisme ekonomi pasar di lahan perkotaan, sehingga kenaikan harga lahan dan properti sebagai implikasi dari hal tersebut memberatkan masyarakat yang kurang mampu sehingga mereka terusir dari hunian asalnya [10]. Literatur yang mencoba menjelaskan faktorfaktor motivasi mengapa pada akhirnya selalu ada golongan masyarakat yang "pergi" adalah karena kecenderungan masyarakat untuk mencari kawasan hunian yang mereka temui memiliki karakter masyarakat yang serupa sehingga mereka mampu membangun interaksi yang baik [11]. Selain itu pendapat lain mengemukakan bahwa faktor pendorong mengapa masyarakat semula pergi dari hunian asalnya adalah karena masyarakat mungkin merasa budaya dan norma komunitas menjadi hilang [12]. Maka dari itu, kenyamanan masyarakat untuk tinggal di kawasan hunian mereka sendiri menjadi berkurang.

Dalam perdebatannya, istilah gentrifikasi seringkali dihubung-hubungkan dengan proses displacement atau penggusuran. Namun seiring dengan perkembangan ilmu mengenai gentrifikasi, pendapat-pendapat lainnya mengemukakan bahwa gentrifikasi berbeda dengan proses penggusuran (displacement) [13]. Displacement merupakan proses ketika kelompok masyarakat sudah terpaksa pindah karena tidak mampu menyesuaikan dengan naiknya kebutuhan biaya hidup akibat dari kawasan yang mereka huni telah menghadapi gentrifikasi. Sementara definisi gentrifikasi itu sendiri hanya sampai kepada proses peningkatan kawasan hingga akhirnya dua kelompok sosial pada kasta berbeda hidup berdampingan dan kelompok yang lebih lemah harus menghadapi ketidakadilan ekonomi. Namun begitu, diskusi terkait perdebatan pendefinisian ini berakhir pada kesepakatan bahwa masyarakat yang mengalami fenomena gentrifikasi di kawasan huniannya pada akhirnya memang akan memilih untuk pindah, dan mencari hunian yang serupa dengan kondisi hunian semula mereka. Sehingga pembahasan gentrifikasi tidak bisa terlepas dari hal-hal yang berkaitan dengan displacement.

\section{DAMPAK DARI GENTRIFIKASI DAN MENGAPA MENJADI FENOMENA YANG PERLU PERHATIAN DALAM PERENCANAAN}

Opini mengenai fenomena gentrifikasi biasanya terbagi dari sudut pandang pembuat kebijakan/pemerintah, peneliti, masyarakat terdampak, masyarakat (komentator), dan developer. Dalam menentukan dampak dari gentrifikasi, harus dilihat dari berbagai stakeholder yang terlibat untuk menyimpulkan cost and benefit dari sudut pandang yang komprehensif [14]. Dampak gentrifikasi pada dasarnya dikelompokan menjadi dua, ada yang berkonotasi negatif, maupun sebaliknya (positif) [8]. Hal ini tergantung pada pihak mana yang mengalaminya. Misalnya, kenaikan harga properti justru menguntungkan bagi sebagian penduduk pemilik properti rumah karena meningkatkan nilai properti mereka, namun merugikan bagi penduduk yang berpenghasilan lebih rendah karena keberatannya membayar pajak atau membayar sewa rumah [8].

Namun, berbagai studi membuktikan bahwa konsekuensi gentrifikasi lebih condong kepada dampak negatif. Bukti dari 
dampak negatif gentrifikasi selama ini dilihat dari berbagai isu yang muncul secara luas, dimana studi-studi sebelumnya banyak yang memberikan temuan dampak negatif pada kasus gentrifikasi yang utamanya berdampak pada kawasan permukiman. Sementara itu, bukti dari dampak positif gentrifikasi bukan berdasarkan riset (non-research based), melainkan hanya asumsi-asumsi peneliti dalam riset-riset sebelumnya yang semata-mata hanya sebagai "perceived logic" bahwa gentrifikasi dalam konteks peningkatan kawasan pastinya memiliki dampak positif.

Konsekuensi dari fenomena gentrifikasi ada yang bersifat positif maupun negatif yang mempengaruhi dua aspek, yaitu ekonomi dan sosial [15]. Adapun konotasi positif ini justru membuat fenomena gentrifikasi ini 'disambut' karena menguntungkan beberapa pihak, seperti pemerintah pengusaha real estate, investor, pemerintah (keuntungan ekonomi dari pungutan pajak), atau bahkan sebagian masyarakat penghuni. Dampak negatif gentrifikasi pada umumnya menimpa masyarakat berpenghasilan rendah, yang berakhir pada proses Displacement.

Dampak-dampak tersebut merupakan keutamaan hingga akhirnya gentrifikasi merupakan fenomena yang penting untuk dibahas dalam proses perencanaan. Pada kenyataannya, fenomena gentrifikasi selalu membawa ancaman terhadap masyarakat permukiman kelas bawah, memunculkan suatu isu ketidakadilah/segregasi sosial. Maka dari itu usaha-usaha untuk mengintervensi keadaan ketika gentrifikasi muncul adalah dengan mengembangkan komunikasi kepada komunitas yang sedang menghadapi ancaman gentrifikasi. Karena suatu proses perencanaan tidak bisa mengelak bahwa pembangunan fisik untuk peningkatan kawasan adalah perlu, maka komunitas menjadi suatu objek baru untuk dipelajari sehingga memungkinkan perencanaan yang bersifat metadisiplin benarbenar dieksekusi bukan hanya sekadar paham intelektual saja. Namun, perlu juga diakui Indonesia memang proses perencanaan di Indonesa masih mengalami kecanggungan dalam melakukan pendekatan-pendekatan sosial dalam perencanaan [9].

\section{PERKEMBANGAN TEORI PERENCANAAN DAN KRITIK TERHADAP PENDEKATAN PERENCANAAN SPASIAL DI INDONESIA}

Perencanaan sebagai suatu disiplin ilmu biasanya berfokus pada orientasi masa depan [2]. Namun untuk dapat merencanakan masa yang akan datang, perencanaan juga membutuhkan orientasi pada masa sekarang, atau keadaankeadaan eksisting. Karena peluang mengenai apa yang dapat dicapai di masa depan haruslah mempertimbangkan apa yang terjadi pada masa sekarang untuk memberikan pemahaman pada perencana sehingga dapat menyusun apa yang ada di dalam pikiran menuju tindakan-tindakan di lapangan atas dasar ilmu yang dikuasai. Pernyataan tersebut merupakan sebuah ungkapan oleh Friedman [1] ; "Planning is a linkage from knowledge to action", bahwa perencanaan adalah upaya untuk menghubungkan pengetahuan (perencana yang dianggap expert) dan mewujudkannya lewat tindakan (produk perencanaan). Sebuah paradigma perencanaan yang diakui sampai sekarang adalah sebuah produk perencanaan itu harus bersifat rasional. Namun, pertanyaan selanjutnya adalah apa yang disebut dengan "rasional tersebut?". Rasional biasanya mengacu pada kriteria-kriteria formal yang harus dipenuhi. Namun pada perkembangan teori perencanaan, ternyata apa yang dikatakan "rasional" ini mengalami diskusi dan perdebatan sehingga munculah berbagai pandangan terhadap teori perencanaan.

Masih sampai dengan era 60 -an, pendekatan perencanaan masih bersifat keruangan yang meliputi desain lingkungan (fisik) dan permukiman [1]. Namun pada era tersebut perencanaan ternyata menuai kritikan, yaitu:

- Aspek kehidupan sosial kurang mendapat perhatian dalam wilayah perencanaan, yang diistilahkan sebagai social blindnes

- Cenderung berfokus pada aspek fisik dari perencanaan, yang diistilahkan dengan lack of complexity and interrelatedness

Masih pada era yang sama, mulai disadari bahwa perencanaan yang melihat aspek fisik saja tidak cukup. Maka mulailah terbentuk suatu konsepsi yang disebut dengan sociological conception of space, dan bermula suatu paradigma perencanaan yang menganggap rasionalitas juga berkenaan dengan aspek-aspek sosial. Tidak hanya itu, aspek ekonomi juga dianggap sama pentingnya. Trend untuk membangun perkotaan dengan prinsip pembangunan berkelanjutan (mempertimbangkan aspek lingkungan, sosial dan ekonomi) juga bermula pada era ini [2]. Dari sinilah perencanaan menjadi ilmu yang metadisiplin, cakupannya yelah menjadi luas dan dipandang sebagai suatu sistem. Implikasinya adalah hingga pada era modernisasi menjadi begitu banyak pendekatan perencanaan, dan yang paling berkembang di Indonesia adalah pendekatan Rational Comprehensive Planning (RCP). Namun prinsipnya tetap sama, modal pendekatan pada paradigma perencanaan modern masih sepenuhnya bersandar pada pengetahuan perencana (expert).

Indonesia pada dasarnya sampai saat ini masih memegang metode pendekatan RCP. Meskipun sudah mempertimbangkan prinsip-prinsip pembangunan berkelanjutan dalam melakukan proses perencanaan dengan pendekatan RCP, namun pendekatan ini masih dianggap memiliki kekurangan. Konsepsi yang mengakui bahwa pendekatan sosial itu penting tidak akan sepenuhnya berhasil apabila seorang perencana masih diasumsikan sebagai pihak yang tau segalanya [2]. Fakta membuktikan bahwa pengetahuan perencana ternyata selalu mengalami ketertinggalan mengenai apa yang sebetulnya terjadi pada kehidupan sosial di masyarakat. Selanjutnya muncul suatu kendala dimana masyarakat tidak berfungsi sesuai dengan apa yang dipersepsikan oleh perencana.

Fenomena gentrifikasi yang marak terjadi di perkotaan sebenarnya sudah layak mendapatkan perhatian oleh seorang perencana, dan tidak bisa hanya mengintervensi lewat pendekatan-pendekatan tradisional. Hal tersebut dikarenakan kasus gentrifikasi pada setiap kawasan akan memiliki cerita yang berbeda-beda yang disebabkan oleh proses gentrifikasi memiliki pengaruh yang signifikan terhadap respon masyarakat terdampak. Sementara, tentunya karakter 
masyarakat pada setiap kawasan tentunya akan berbeda-beda [16]. Maka dari itu, sudah dapat disimpulkan bahwa perencanaan di Indonesia belum sampai pada tahap dimana fenomena gentrifikasi dapat teridentifikasi, dan diintervensi setelahnya.

Seperti yang sudah dibahas sebelumnya bahwa fenomena gentrifikasi melibatkan berbagai macam pihak terutama pemerintah, investor dan juga masyarakat (multipublik). Maka untuk dapat bisa mengakomodasi pertimbangan-pertimbangan gentrifikasi pada perencanaan maka harus diakui terlebih dahulu bahwa publik tentunya adalah sebagai sesuatu yang plural, dan beranekaragam. Oleh karenanya model-model perencanaan yang perlu berkembang di Indonesia adalah model perencanaan yang menekankan perlunya proses dialog (komunikasi), partisipasi, kolaborasi dan penciptaan konsensus antara pihak-pihak tersebut. Perlunya proses mutual learning untuk menjembatani antara pengetahuan teoritik dari perencana dengan pengetahuan praktis dari masyarakat [17]. Dengan menggunakan perspektif teori tindakan komunikatif beberapa teorisi menekankan pentingnya proses interaktif melalui komunikasi, menekankan perlunya memahami keunikan dari suatu lokasi perencanaan, dan perlunya pendekatan yang lebih bersifat kualitatif. Hal ini merupakan metode yang paling sesuai untuk dapat bisa mengidentifikasi fenomena gentrifikasi di Indonesia, mengingat gentrifikasi merupakan fenomena yang bersifat sangat lokal dan terjadi pada area yang tidak cukup luas, sehingga menjadi proses yang unik pada setiap peristiwanya.

\section{KESIMPULAN}

Gentrifikasi merupakan suatu fenomena perkotaan yang hanya dapat terobservasi apabila perencanaan sudah mengadopsi pendekatan sosial dalam prosesnya, yang menurut studi ternyata di Indonesia masih menjadi hal yang cenderung canggung untuk dibahas. Hal tersebut menjawab mengapa gentrifikasi belum menjadi istilah yang familiar, sangat jarang dibahas, sehingga keberadaan dari fenomena ini juga sangat sulit teridentifikasi. Pendekatan perencanaan Rational Comprehensive Planning juga ternyata belum dapat sepenuhnya mengakomodasi masalah-masalah yang berkaitan dengan isu sosial di perkotaan. Gentrifikasi sekarang sudah diakui sebagai fenomena yang penting dibahas dalam ilmu perkotaan. Apabila Indonesia ingin berada pada capaian dimana fenomena ini juga turut dipertimbangkan dalam perencanaan demi menghasilkan produk rencana yang memperhatikan kepentingan multi publik, maka pendekatan perencanaan harus mulai mengarah pada pendekatan komunikatif dimana proses interaktif menjadi suatu hal yang berarti.

\section{DAFTAR PUSTAKA}

[1] J. Friedman, Planning in The Public Domain, Princeton University Press, Okford.W.-K. Chen, Linear Networks and Systems (Book style). Wadsworth Publishing Company, 1987.

[2] A. Masik, "Hubungan Modal Sosial dan Perencanaan," J. Perenc. Wil. dan Kota, vol. 16, no. 3, pp. 1-23, 2005.

[3] M. P. Brooks, Planning Theory for Practitioners. Chicago: American Planning Association, 2002.

[4] N. Smith, The New Urban Frontier. New York: Routledge, 1996.

[5] L. Keating, "Gentrification: Policy, Politics, and Policies," Morehouse College, 2003.

[6] L. Freeman, "Still Separate and Unequal: The State of Fair Housing in America," Natl. Comm. Fair Hous. Equal Oppor., 2008.

[7] W. Martokusumo, "Revitalisasi, Sebuah Pendekatan dalam Peremajaan Kawasan," 2008.

[8] R. Atkinson, "Does gentrification help or harm urban neighbourhoods?: An assessment of the evidence-base in the context of the new urban agenda (CNR paper 5)," ESRC Cent. Neighb. Res., 2002.

[9] R. Munir, "Merencana di Tengah Jerat Hutang, dalam Winarso," ITB, 2002.

[10] R. L. Glass, Aspect of Change. London: MacGibbon \& Kee, 1964.

[11] G. Butler, T., \& Robson, "Negotiating Their Way In: The Middle Classes, Gentrification and the Deployment of Capital in a Globalizing Metropolis," 2003.

[12] S. Brown, Beyond Gentrification: Strategies for Guiding the Conversation and Rediricting the Outcomes of Community Transition. Cambridge: Joint Centre for Housing Studies of Harvard University, 2014.

[13] L. Freeman, Displacement or Succession? Residential Mobility in Gentrifying Neighborhoods. 2005.

[14] Lang. M.E, Gentrification Amid Urban Decline: Strategies for Americas Older ities. Cambridge: Ballinger, 1982.

[15] E. Aka. Jr, Gentrification and Socioeconomic Impacts of Neighborhood Integration and Diversification in Atlanta, Georgia. Morehouse College, 2001.

[16] M.-J. Bang, "Understanding Centrification: The Role and Abilities of Community Based Organization in Changing Neighborhoods, A Case Study of Post-Katrina New Orleans," The University of Texas at Arlington, 2010.

[17] L. Sandercock, Towards Cosmopolis: Planning for Multicultural Cities. Brisbane: John Wiley \& Sons Ltd, 1998. 